\title{
PATERNIDADE SOCIOAFETIVA: ASPECTOS POLÊMICOS. DOUTRINA E JURISPRUDÊNCIA
}

\author{
Felipe Cunha de Almeida ${ }^{1}$
}

\section{INTRODUÇÃO}

O estudo em questão trata de abordar o instituto da paternidade socioafetiva, ou seja, aquela situação de fato e que envolve determinada criança e o seu pai, ou mãe, e quando superados alguns requisitos, como por exemplo, o afeto, impõe ao pai a condição da paternidade. Assim, além do entendimento doutrinário, faremos um paralelo com a jurisprudência do Superior Tribunal de Justiça, do Tribunal de Justiça do Rio Grande do Sul e de outros Tribunais estaduais, com o objetivo de verificação da demonstração dos conceitos aqui trazidos, sob a ótica do Poder Judiciário. Aspectos como a posse de estado de filho, paternidade socioafetiva, adoção à brasileira e, inclusive, a questão criminal da conduta tipificada e prevista pelo art. 242 do Código Penal, além das hipóteses de investigação do vínculo biológico, mesmo quando comprovada a paternidade socioafetiva, bem como hipóteses quanto ao cancelamento dos registros, também serão tratadas.

Pontes de Miranda, ao ensinar sobre o direito de família, afirma que o seu objeto é a exposição de princípios jurídicos que regem as relações familiares, e seja a influência dessas relações sobre as pessoas, seja sobre os seus bens. Quanto à divisão do direito de família, este se configura em duas partes: a) a que estuda a socieda-

1 Mestrando pela Universidade Federal do Rio Grande do Sul (UFRGS) em Direito Civil, professor, advogado, especialista em Direito Civil e Processual Civil com ênfase em Direito Processual Civil. E-mail: professorfelipecunha@hotmail.com. 
de conjugal (capacidade, celebração, chefia etc.) e em suas consequências morais, pessoais e patrimoniais: sucessão do cônjuge, por exemplo; b) a que se destina ao estudo da sociedade parental: normas sobre a fixação dos parentescos, tutela, curatela, ausência etc. $^{2}$ A finalidade da legislação em matéria de direito de família é a de regular e proteger a vida dos casais, assegurar a procriação dentro dos limites da lei, fixar o que é parentesco jurídico. ${ }^{3}$

A ideia que vigorava no passado sobre a natureza jurídica da família era a de que formava uma pessoa jurídica. E a base de tal raciocínio fundava-se no aspecto de que a família era a detentora de direitos extrapatrimoniais, tais como o nome e o então pátrio-poder (atualmente, de acordo com o Código Civil de 2002, o poder familiar). Todavia, esse posicionamento foi superado, eis que, segundo a doutrina, muito impreciso o conceito. ${ }^{4}$

$\mathrm{O}$ direito brasileiro, bem como na tradição ocidental, entende que a família não pode ser considerada como pessoa jurídica, pois é nítida a ausência de capacidade e aptidão para usufruir de direitos e obrigações. Tanto os direitos patrimoniais como os direitos imateriais concernentes à família (poder familiar, nome, por exemplo), traduzem-se nos direitos subjetivos de cada membro. De tal sorte que os titulares de direitos e deveres são os membros considerados de forma individual, e não a família. Sílvio Venosa assevera que a família é conceituada como instituição, ponderando que, apesar de tal posicionamento vir da doutrina majoritária, não reflete posição homogênea. ${ }^{5}$

O Diploma de 2002, adaptado e seguindo a Constituição Federal de 1988, busca aproximar-se da mais alta igualdade jurídica entre os cônjuges, companheiros, abarcando também a igualdade jurídica entre os filhos, independentemente de sua origem. De forma a que o Estado não fique ausente quanto ao cumprimento permanente da função social de proteção à família, esta como própria célula mater, que é. ${ }^{6}$

2 PONTES DE MIRANDA; Francisco Cavalcanti. Tratado de direito de família. V. 1: Direito matrimonial. ALVES, Vilson Rodrigues (Atual.). 1. ed. Campinas: Bookseller, 2001, p. 75.

3 Idem, p. 81.

4 VENOSA, Sílvio de Salvo. Direito de família. 11. ed. São Paulo: Atlas, 2011 p. 7.

5 Idem, p. 8.

6 Idem, p. 9. 
A família tem proteção integral. Como leciona o professor doutor Carlos Silveira Noronha, analisando e discorrendo sobre a evolução da família, perante o direito divino e o direito canônico, aquela é considerada pelas Escrituras como entidade de direito divino, e tem origem exclusivamente no casamento. A finalidade, também, era de santificar a união indissolúvel do homem e da mulher. O caráter sacramental do matrimônio (casamento religioso) foi reafirmado pela Igreja, no Concílio de Trento, realizado entre 1545 e 1563 . De tal sorte que o casamento é solidificado na cellula mater. ${ }^{7}$

Portanto, o direito de família tem como principal característica a tutela do ente familiar, dos bens que the são próprios, da prole, bem como dos demais interesses afins. E com mais razão acentua Arnaldo Rizzardo que a sua destinação é, de forma prática, colocada como um direito público, ou quase público, eis que, nos termos da Constituição Federal (art. 226), é função do Estado a sua proteção. Inclusive, em decorrência desta circunstância, desta peculiaridade, ensina o autor referido que existe certa limitação em relação à disponibilidade de direitos. De tal sorte que não cabe às partes pactuar de forma diferente da estabelecida em lei, tais como o casamento, filiação, alimentos. ${ }^{8}$

A afeição agrega um significado mais profundo do que a realidade biológica. Embora a legislação atual não reconheça a filiação socioafetiva, tanto a doutrina como a jurisprudência a prestigiam, no que concerne a denominada posse de estado de filho, essa a representação do substrato fático de verdadeira e única filiação, sustentada no amor e no desejo de ser pai ou mãe ${ }^{9}$.

A Constituição Federal apresenta um extenso rol quanto a direitos individuais e sociais, com o objetivo de garantir dignidade a todos. Como se não bastasse, o Estado impõe a si obrigações para com os seus cidadãos. Esse compromisso assumido, segundo os ensinamentos de Maria Berenice Dias, é o de assegurar o afeto, e o primeiro a ser obrigado a assegurar o afeto deve ser o próprio Estado, em que pese à expressão afeto não constar no texto constitucional. A união estável é característica marcante do afeto, tanto que adquiriu reconhecimento e foi inserida no ordenamento jurídico. E mais: o afeto, segundo a autora, foi consagrado em nível de direito fun-

7 NORONHA, Carlos Silveira. Fundamentos e evolução histórica da família na ordem jurídica. Direito \& Justiça, V. 20, ano XXI, 1999, p. 58-60.

8 RIZZARDO, Arnaldo. Direito de família. 8. ed. Rio de Janeiro: Forense, 2011, p. 4-5. 9 MADALENO, Rolf. Curso de direito de família. 5. ed. Rio de Janeiro: Forense, 2013, p. 488. 
damental, e tal consequência é, por exemplo, a igualdade entre irmãos biológicos e adotivos. ${ }^{10}$

$O$ afeto não guarda origem na biologia. Os seus laços, tanto de afeto quanto de solidariedade, derivam da convivência em família, e não do sangue. A título de exemplo, a posse de estado de filho traduz-se no reconhecimento jurídico do afeto, objetivando, desse modo, garantir a felicidade, esta como direito de ser almejado. E mais: o afeito não é somente um laço que envolve integrantes de uma mesma família, ele tem uma conotação externa, entre as famílias. ${ }^{11} \mathrm{O}$ Superior Tribunal de Justiça, ao analisar demanda envolvendo pedido de ação negatória de paternidade, direciona-se no mesmo sentido do raciocínio trazido, quando, em sua fundamentação, o Relator assevera que "O estado de filiação decorre da estabilidade dos laços construídos no cotidiano do pai e do filho (afetividade) ou da consanguinidade". ${ }^{2}$

10 DIAS, Maria Berenice. Manual de direito das famílias. 6. ed. São Paulo: Revista dos Tribunais, 2010, p. 70.

11 Idem.

12 RECURSO ESPECIAL. DIREITO CIVIL E PROCESSUAL CIVIL. FAMÍLIA. AÇÃO NEGATÓRIA DE PATERNIDADE. LEGITIMIDADE ORDINÁRIA ATIVA. AÇÃO DE ESTADO. DIREITO PERSONALÍSSIMO E INDISPONÍVEL DO GENITOR (ART. 27 DO ESTATUTO DA CRIANÇA E DO ADOLESCENTE). SUB-ROGAÇÃO DOS AVÓS. IMPOSSIBILIDADE. EXAME DE DNA. RESULTADO DIVERSO DA PATERNIDADE REGISTRAL. AUSÊNCIA DE VÍNCULO DE PARENTESCO ENTRE AS PARTES. FILIAÇÃO AFETIVA NÃO CONFIGURADA. ESTADO DE FILIAÇÃO RECONHECIDO VOLUNTARIAMENTE PELO PAI BIOLÓGICO. SUPREMACIA DO INTERESSE DO MENOR. VERDADE REAL QUE SE SOBREPÕE À FICTÍCIA. ART. 511, § $2^{\circ}$, DO CPC. AUSÊNCIA DE NULIDADE. PAS DE NULLITÉ SANS GRIEF. REEXAME DE MATÉRIA FÁTICO-PROBATÓRIA. INVIABILIDADE. SÚMULAS No 83, 211, 7/STJ E 284/STF. INCIDÊNCIA.

1. A legitimidade ordinária ativa da ação negatória de paternidade compete exclusivamente ao pai registral por ser ação de estado, que protege direito personalíssimo e indisponível do genitor (art. 27 do ECA), não comportando sub-rogação dos avós, porquanto direito intransmissível, impondo-se manter a decisão de carência de ação (art. 267, VI, do CPC), mormente quando o interesse dos recorrentes não é jurídico, mas meramente afetivo e patrimonial.

2. O estado de filiação decorre da estabilidade dos laços construídos no cotidiano do pai e do filho (afetividade) ou da consanguinidade.

3. A realização do exame pelo método DNA apto a comprovar cientificamente a inexistência do vínculo genético confere ao marido a possibilidade de obter, por meio de ação negatória de paternidade, a anulação do registro ocorrido com vício de consentimento. 
4. O erro a que foi induzido o pai registral de criança nascida na constância do seu casamento com a genitora, com quem o suposto pai não estreitou afetividade suficiente para que desfrutasse da paternidade socioafetiva (posse de estado de filho), desafia a eficácia constitutiva negativa de estado pleiteada na inicial, com a consequente alteração do registro público de nascimento da criança, para fazer constar o nome do pai biológico, excluindo-se, consectariamente, o nome dos avós registrais paternos.

5. O registro público tem por princípio conferir segurança jurídica às relações civis e deve espelhar a verdade real e não fictícia.

6. É consectário da dignidade humana que os documentos oficiais de identificação reflitam a veracidade dos fatos da vida, desde que a retificação não atente contra a ordem pública.

7. O princípio da supremacia do interesse do menor impõe que se assegure seu direito ao reconhecimento do verdadeiro estado de filiação, que já é voluntariamente exercida pelo pai biológico.

8. Não há falar em negativa de prestação jurisdicional se o tribunal de origem motiva adequadamente sua decisão, solucionando a controvérsia com a aplicação do direito que entende cabível à hipótese, apenas não no sentido pretendido pela parte.

9. A ausência de prequestionamento da matéria suscitada no recurso especial, a despeito da oposição de embargos declaratórios, impede o conhecimento do recurso especial (Súmula n ${ }^{\circ} 211 / \mathrm{STJ}$ ).

10. A mera circunstância de não haver o "visto" do revisor que recebe os autos em seu gabinete, pede dia para julgamento e participa plenamente da sessão não contrária ao art. 511, $\S 2^{\circ}$, do Código de Processo Civil, à falta de nulidade processual e da demonstração de qualquer prejuízo às partes (pas de nullité sans grief).

11. A reforma do julgado demandaria interpretação de matéria fático-probatória, procedimento vedado na estreita via do recurso especial, a teor da Súmula ${ }^{\circ}$ 7/STJ.

12. A perfeita harmonia entre o acórdão recorrido e a jurisprudência dominante desta Corte impõe a aplicação, à hipótese dos autos, do enunciado n. 83 da Súmula do Superior Tribunal de Justiça.

13. A divergência jurisprudencial com fundamento na alínea "c" do permissivo constitucional, nos termos do art. 541, parágrafo único, do Código de Processo Civil e do art. $255, \S 1^{\circ}$, do Regimento Interno do Superior Tribunal de Justiça, requisita comprovação e demonstração, esta, em qualquer caso, com a transcrição dos trechos dos acórdãos que configurem o dissídio, a evidenciar a similitude fática entre os casos apontados e a divergência de interpretações.

14. Tendo sido interposto à moda de apelação, ou seja, deixando de indicar especificamente de que forma teria o acórdão incorrido na violação de dispositivos legais sequer apontados para configurar suposta nulidade processual, o recurso especial encontra-se inviabilizado nesta instância especial, a teor da Súmula $n^{\circ} 284$ do Supremo Tribunal Federal.

15. Recurso especial parcialmente conhecido, e nesta parte, desprovido. (REsp 1328306 / DF, STJ, $3^{\text {a }}$ Turma, Rel. Min. Ricardo Villas Bôas Cueva, julgado em: 14/05/2013). Disponível em: $<$ https://ww2.stj.jus.br/revistaeletronica/Abre_Documento.asp?sSeq=1233935 $\&$ sReg=201201206577\&sData=20130520\& formato=HTML $>$. Acesso em: 28 mar. 2014. 
Portanto, podemos observar a importância que o ordenamento jurídico confere à família e aos vínculos que ela forma entre os seus integrantes, sejam estes biológicos e ou por uma situação de fato, cujo afeto esteja presente. De tal sorte que, a partir dos tópicos seguintes, enfrentaremos a questão da filiação socioafetiva.

\section{POSSE DE ESTADO DE FILHO}

Maria Berenice Dias, ao ensinar sobre a posse do estado de filho, assevera que, quando as pessoas desfrutam de uma determinada situação jurídica que não corresponde à verdade, tem-se o que se denomina de posse de estado. Como se não bastasse, a noção da posse de estado de pai deve também se comprovar, eis que reflete a reciprocidade com a posse de estado de filho, ou seja: uma não pode existir sem a outra. ${ }^{13}$

A aparência faz com que todos venham a acreditar na existência de uma situação que não é verdadeira. $\mathrm{E}$ tal circunstância não pode ser objeto de desprezo pelo direito. Assim, "a tutela da aparência acaba emprestando juridicidade a manifestações exteriores de uma realidade que não existe". Maria Berenice Dias, utilizando-se dos ensinamentos de Luiz Edson Fachin, aduz que os vínculos de parentalidade fornecem exemplos para a teoria da aparência, ou seja, o vínculo da paternidade não é tão somente um dado, ele tem a natureza de se deixar construir. ${ }^{14}$

Nelson Nery Junior e Rosa Maria de Andrade Nery explicam, com base na doutrina de Pontes de Miranda, que existem fatos que importam ao direito por the trazer consequências, criando ou extinguindo situações jurídicas existentes. A afetividade, por sua vez, é um desses fatos que interessa ao direito, podendo, inclusive, criar uma forma de parentesco. Continuam os autores referindo que o reconhecimento da paternidade pode se dar pelo reconhecimento do filho que não tem laços de sangue com aquele que manifesta a vontade de se declarar pai ou mãe, ou que se apresentou, conduziu em sua vida privada de maneira a criar esse vínculo de outra origem ${ }^{15}$. Silvio Venosa ensina que a expressão "outra origem" também pode identificar a posse de estado de filho, que, de

13 DIAS, Maria Berenice. Manual de direito das famílias. 6. ed. São Paulo: Revista dos Tribunais, 2010, p. 366.

14 Idem.

15 JUNIOR, Nelson Nery; NERY, Rosa Maria de Andrade. Código Civil Comentado. 10. ed.. São Paulo, Revista dos Tribunais, 2013, p. 1.593. 
certa forma, complementa a noção de paternidade socioafetiva ${ }^{16}$.

Maria Helena Diniz, lecionando sobre os modos de reconhecimento dos filhos, em especial ao reconhecimento voluntário, explica que, a partir da declaração de vontade no sentido de reconhecimento, tal ato passa a ser irrevogável ou irretratável, inclusive, até, se feito por testamento. É que o ato implica em uma confissão de maternidade ou de paternidade, que só pode ser passível de anulação quando comprovados os vícios da vontade, como dolo ou erro, ou então quando não observadas as formalidades legais. Portanto, o reconhecimento determina o estado de filho, este então irrevogável. ${ }^{17}$

Em que pese a doutrina trazida acerca da posse de estado de filho, o sistema jurídico não a prevê de forma expressa. De tal sorte que a noção da posse de estado de filho não é estabelecida através do nascimento, mas sim por um ato de vontade que se sustenta no terreno da afetividade, circunstância esta que coloca em xeque a verdade jurídica e a certeza científica da filiação. Portanto, a paternidade socioafetiva assenta-se no reconhecimento da posse de estado de filho. ${ }^{18}$

Três são os aspectos trazidos pela doutrina no tocante ao reconhecimento da posse de estado de filho, a saber: a) tractus: quando o filho é tratado como tal, criado, educado e apresentado como filho pelo pai e pela mãe; b) nominativo: usa o nome da família, e assim também se apresenta; c) reputatio: a criança é conhecida pela sociedade como integrante, pertencente à família de seus pais, ou seja, "confere à aparência os efeitos da verossimilhança que o direito considera como satisfatória". ${ }^{19}$

\section{PATERNIDADE SOCIOAFETIVA}

A filiação que resulta da posse de estado de filho constitui modalidade de parentesco civil de outra origem, de acordo com a diç̧ão do art. 1.593 do Código Civil ${ }^{20}$, ou seja, tem ori-

16 VENOSA, Silvio de Salvo. Código Civil Interpretado. São Paulo: Atlas, 2010, p. 1.450 .

17 DINIZ, Maria Helena. Curso de direito civil brasileiro, V 5: Direito de família. 27. ed. São Paulo: Saraiva, 2012, p. 522-523.

18 DIAS, Maria Berenice. Manual de direito das famílias. 6. ed. São Paulo: Revista dos Tribunais, 2010, p. 366.

19 Idem.

20 "Art. 1.593. O parentesco é natural ou civil, conforme resulte de consanguinidade ou outra origem". 
gem afetiva. Corresponde, portanto, à verdade aparente e decorre do direito à filiação. À verdade biológica é atribuído um papel secundário, em razão da necessidade de se manter a estabilidade da família ${ }^{21}$.

Assim, a verdade real é o fato de o filho gozar da posse de estado, que faz a prova do vínculo parental. Zeno Veloso, referenciado por Maria Berenice Dias, assevera que, na hipótese de o genitor, além de ter um comportamento notório e contínuo, confessar, de forma reiterada, que é o pai de determinada criança, propagando tal circunstância no meio em que vive, não há razão, seja moral e ou ética, mesmo que não exista registro da filiação, para que o filho reivindique a paternidade ${ }^{22}$.
O Superior Tribunal de Justiça também aplica em seus julgamentos o princípio do melhor interesse da criança no sentido de ressaltar a questão da convivência entre a criança e o pai afetivo. Nesta decisão, a Corte considerou que, em discussão envolvendo cadastro de adoção, a observância do cadastro de adotantes, ou seja, a preferência das pessoas cronologicamente cadastradas para adotar determinada criança não é absoluta. A regra comporta exceções determinadas pelo princípio do melhor interesse da criança. Assim, quando já formado forte vínculo afetivo entre a criança e o pretendente à adoção, o convívio foi determinante no sentido de estabelecer o vínculo de afetividade da criança com os pais adotivos. ${ }^{23}$

21 DIAS, Maria Berenice. Manual de direito das famílias. 6. ed. São Paulo: Revista dos Tribunais, 2010, p. 366.

22 Idem, p. 367.

23 "RECURSO ESPECIAL - ADOÇÃO - CADASTRO DE ADOTANTES - RELATIVIDADE - PRINCÍPIO DA PREVALÊNCIA DO INTERESSE DO MENOR - VÍNCULO AFETIVO DA MENOR COM CASAL DE ADOTANTES DEVIDAMENTE CADASTRADOS - PERMANÊNCIA DA CRIANÇA POR APROXIMADAMENTE DOIS ANOS, NA SOMATÓRIA DO TEMPO ANTERIOR E DURANTE O PROCESSO - ALBERGAMENTO PROVISÓRIO A SER EVITADO - ARTIGO 197-E, § 1 ${ }^{\circ}$, DO ECA - PRECEDENTES DESTA CORTE - RECURSO ESPECIAL PROVIDO.

1. A observância do cadastro de adotantes, ou seja, a preferência das pessoas cronologicamente cadastradas para adotar determinada criança, não é absoluta. A regra comporta exceções determinadas pelo princípio do melhor interesse da criança, base de todo o sistema de proteção. Tal hipótese configura-se, por exemplo, quando já formado forte vínculo afetivo entre a criança e o pretendente à adoção, ainda que no decorrer do processo judicial. Precedente.

2. No caso dos autos, a criança hoje com 2 anos e 5 meses, convivia com os recorrentes há um ano quando da concessão da liminar (27.10.2011), permanecendo até os dias 
Trazemos julgado que tratou de deferir ao filho, mesmo vivenciando a situação quanto à paternidade socioafetiva, a possibilidade de investigação do seu vínculo biológico. Como observamos do voto do relator: "Afastar a possibilidade de o filho pleitear $\mathrm{o}$ reconhecimento da paternidade biológica, no caso de 'adoção à brasileira', significa impor-lhe que se conforme com essa situação criada à sua revelia e à margem da lei". ${ }^{24}$ Já nesta outra

atuais. Esse convívio, sem dúvida, tem o condão de estabelecer o vínculo de afetividade da menor com os pais adotivos.

3. Os Recorrentes, conforme assinalado pelo Acórdão Recorrido, já estavam inscritos no Cadastro Único Informatizado de Adoção e Abrigo (CUIDA), o que, nos termos do artigo 197-E, do ECA, permite concluir que eles estavam devidamente habilitados para a adoção. Além disso, o $\S 1^{\circ}$, do mesmo dispositivo legal afirma expressamente que "A ordem cronológica das habilitações somente poderá deixar de ser observada pela autoridade judiciária nas hipóteses previstas no $\S 13$ do art. 50 desta Lei, quando comprovado ser essa a melhor solução no interesse do adotando".

4. Caso em que, ademais, a retirada do menor da companhia do casal com que se encontrava há meses devia ser seguida de permanência em instituição de acolhimento, para somente após, iniciar-se a busca de colocação com outra família, devendo, ao contrário, ser a todo o custo evitada a internação, mesmo que em caráter transitório.

5. A inobservância da preferência estabelecida no cadastro de adoção competente, portanto, não constitui obstáculo ao deferimento da adoção quando isso refletir no melhor interesse da criança.

6. Alegações preliminar de nulidade rejeitadas.

7. Recurso Especial provido. (REsp 1347228 / SC, STJ, $3^{\mathrm{a}}$ Turma, Rel. Min. Sidnei Beneti, julgado em: 06/11/2012). Disponível em: $<$ https:/ww2.stj.jus.br/revistaeletronica/Abre_Documento.asp?sSeq $=1192115 \&$ sReg $=201200965571 \&$ sData $=20121120$ \&formato=HTML $>$. Acesso em: 28 mar. 2014.

24 DIREITO DE FAMÍLIA. RECURSO ESPECIAL. AÇÃO INVESTIGATÓRIA DE PATERNIDADE E MATERNIDADE AJUIZADA PELA FILHA. OCORRÊNCIA DA CHAMADA “ADOÇÃO À BRASILEIRA”. ROMPIMENTO DOS VÍNCULOS CIVIS DECORRENTES DA FILIAÇÃO BIOLÓGICA. NÃO OCORRÊNCIA. PATERNIDADE E MATERNIDADE RECONHECIDOS.

1. A tese segundo a qual a paternidade socioafetiva sempre prevalece sobre a biológica deve ser analisada com bastante ponderação, e depende sempre do exame do caso concreto. É que, em diversos precedentes desta Corte, a prevalência da paternidade socioafetiva sobre a biológica foi proclamada em um contexto de ação negatória de paternidade ajuizada pelo pai registral (ou por terceiros), situação bem diversa da que ocorre quando o filho registral é quem busca sua paternidade biológica, sobretudo no cenário da chamada "adoção à brasileira".

2. De fato, é de prevalecer a paternidade socioafetiva sobre a biológica para garantir direitos aos filhos, na esteira do princípio do melhor interesse da prole, sem que, ne- 
decisão, houve, de início, o reconhecimento da paternidade, através de escritura pública, levada ao Registro Civil. Todavia e posteriormente, o exame de DNA comprovou situação diversa, havendo pretensão, com base nesta prova, de negação da paternidade. $\mathrm{O}$ entendimento da Corte, contu- do, foi no sentido de que "Fica evidenciado que o Tribunal a quo, com base no conjunto probatório, entendeu não restar caracterizado o vício de consentimento apto a ensejar a nulidade pretendida, concluindo conforme orientação emanada da Terceira Turma desta Corte Superior ${ }^{25}$ ".

cessariamente, a assertiva seja verdadeira quando é o filho que busca a paternidade biológica em detrimento da socioafetiva. No caso de ser o filho - o maior interessado na manutenção do vínculo civil resultante do liame socioafetivo - quem reivindica estado contrário ao que consta no registro civil, socorre-lhe a existência de "erro ou falsidade" (art. 1.604 do CC/02) para os quais não contribuiu. Afastar a possibilidade de o filho pleitear o reconhecimento da paternidade biológica, no caso de "adoção à brasileira", significa impor-lhe que se conforme com essa situação criada à sua revelia e à margem da lei.

3. A paternidade biológica gera, necessariamente, uma responsabilidade não evanescente e que não se desfaz com a prática ilícita da chamada "adoção à brasileira", independentemente da nobreza dos desígnios que a motivaram. E, do mesmo modo, a filiação socioafetiva desenvolvida com os pais registrais não afasta os direitos da filha resultantes da filiação biológica, não podendo, no caso, haver equiparação entre a adoção regular e a chamada "adoção à brasileira".

4. Recurso especial provido para julgar procedente o pedido deduzido pela autora relativamente ao reconhecimento da paternidade e maternidade, com todos os consectários legais, determinando-se também a anulação do registro de nascimento para que figurem os réus como pais da requerente. (REsp 1167993 / RS, STJ, 4 ${ }^{\mathrm{a}}$ Turma, Rel. Min. Luis Felipe Salomão, julgado em: 18/12/2012)". Disponível em: <https://ww2.stj.jus. $\mathrm{br} /$ revistaeletronica/Abre_Documento.asp?sSeq=1189843\&sReg=200902209722\&sData $=20130315 \&$ formato $=$ HTML $>$. Acesso em: 10 abr. 2014.

25 DIREITO CIVIL - FAMÍLIA - AÇÃO NEGATÓRIA DE PATERNIDADE - ALEGAÇÃO DE OFENSA AO ART. 535 DO CPC - INEXISTÊNCIA - REEXAME DO CONJUNTO FÁTICO-PROBATÓRIO - IMPOSSIBILIDADE - SÚMULA 7/STJ INTERESSE MAIOR DA CRIANÇA - VÍCIO DE CONSENTIMENTO NÃO COMPROVADO.

1. Reconhecida a paternidade, por escritura pública, levada ao Registro Civil, não há amparo para que o genitor venha ulteriormente a negá-la, ainda que, por exame de DNA, seja excluída a paternidade biológica, não prejudicando o reconhecimento o fato de o Acórdão recorrido aludir à sua realização como "adoção à brasileira".

2. A jurisprudência desta Casa é pacífica ao proclamar que, se os fundamentos adotados bastam para justificar o concluído na decisão, o julgador não está obrigado a rebater, um a um, os argumentos utilizados pela parte. 


\subsection{Efeitos jurídicos}

A paternidade socioafetiva, quando comprovada, também produz os seus efeitos no campo patrimonial além da esfera pessoal. Assim, o vínculo estabelecido decorrente da filiação socioafetiva, esta que tem legitimidade no interesse do filho, gera o parentesco socioafetivo, e para todos os fins de direito, nos limites da lei civil, como leciona Maria Berenice Dias, de sorte que, se em menor grau, funda-se no princípio do melhor interesse da criança e do adolescente. E, se em maior grau, tem como base o princípio da dignidade da pessoa humana, este que não tolera, não admite o parentesco restrito ou então de segunda classe. Quanto ao princípio da solidariedade, este é aplicado a ambos os casos. ${ }^{26}$

O Superior Tribunal de Justiça também se manifestou no mesmo sentido do posicionamento acima. A Relatora, ao tratar da paternidade socioafetiva e do consequente direito sucessório, assim decidiu: "A paternidade traz em seu bojo diversas responsabilidades, sejam de ordem moral ou patrimonial, devendo ser assegurados os direitos sucessórios decorrentes da comprovação do estado de filiação". ${ }^{27}$

3. O acolhimento das alegações do Recorrente não dispensa o reexame de prova, após os quais se poderia concluir, como pretendido, pela validade do registro de paternidade. Rever a conclusão a que chegou o Tribunal a quo demandaria a incursão no conjunto probatório para concluir-se da forma requerida pelo Recorrente. Incide nesse ponto a Súmula $7 /$ STJ.

4. Fica evidenciado que o Tribunal a quo, com base no conjunto probatório, entendeu não restar caracterizado o vício de consentimento apto a ensejar a nulidade pretendida, concluindo conforme orientação emanada da Terceira Turma desta Corte Superior.

5. Recurso Especial improvido. (REsp 1098036/GO, STJ, $3^{\text {a }}$ Turma, Rel. Min. SIDNEI BENETI, julgado em: 23/08/2011). Disponível em: <https:/ww2.stj.jus.br/ revistaeletronica/Abre_Documento.asp?sSeq=1083493\&sReg=200802396702\&sData $=20120301 \&$ formato $=H T M L>$. Acesso em: 10 abr. 2014.

26 DIAS, Maria Berenice. Manual de direito das famílias. 6. ed. São Paulo: Revista dos Tribunais, 2010, p. 368.

27 "FAMÍLIA. FILIAÇÃO. CIVIL. RECURSO ESPECIAL. AÇÃO DE INVESTIGAÇÃO DE PATERNIDADE E PETIÇÃO DE HERANÇA. VÍNCULO BIOLÓGICO. PATERNIDADE SOCIOAFETIVA. IDENTIDADE GENÉTICA. ANCESTRALIDADE. DIREITOS SUCESSÓRIOS. ARTIGOS ANALISADOS: ARTS. 1.593; $1.604 \mathrm{e}$ 1.609 do Código Civil; ART. 48 do ECA; e do ART. $1^{\circ}$ da Lei 8.560/92.

1. Ação de petição de herança, ajuizada em 07.03.2008. Recurso especial concluso ao Gabinete em 25.08.2011.

2. Discussão relativa à possibilidade do vínculo socioafetivo com o pai registrário impedir o reconhecimento da paternidade biológica. 


\section{ADOÇÃO À BRASILEIRA E PATERNIDADE SOCIOAFETIVA}

Arnaldo Rizzardo assevera que, nos últimos tempos, a adoção à brasileira ou socioafetiva tem sido alvo de muitas discussões. Explica o autor que esse tipo de adoção acontece sem a ocorrência do devido processo legal, e que resulta do reconhecimento de um estado de fato existente por certo período de tempo. Assim, aquele que, mesmo sabedor de não ser o pai biológico faz o registro, expressando a correspondente manifestação de vontade, não pode, posteriormente, negar tal condição. É que se tipifica uma verdadeira adoção em decorrência dessa circunstância, há valor para a pessoa humana, adquirindo feição jurídica a situação revelada em uma verdadeira relação entre pai e filho. Inclusive por questões de herança, não tem

3. A maternidade/paternidade socioafetiva tem seu reconhecimento jurídico decorrente da relação jurídica de afeto, marcadamente nos casos em que, sem nenhum vínculo biológico, os pais criam uma criança por escolha própria, destinando-lhe todo o amor, ternura e cuidados inerentes à relação pai-filho.

4. A prevalência da paternidade/maternidade socioafetiva frente à biológica tem como principal fundamento o interesse do próprio menor, ou seja, visa garantir direitos aos filhos face às pretensões negatórias de paternidade, quando é inequívoco (i) o conhecimento da verdade biológica pelos pais que assim o declararam no registro de nascimento e (ii) a existência de uma relação de afeto, cuidado, assistência moral, patrimonial e respeito, construída ao longo dos anos.

5. Se é o próprio filho quem busca o reconhecimento do vínculo biológico com outrem, porque durante toda a sua vida foi induzido a acreditar em uma verdade que the foi imposta por aqueles que o registraram, não é razoável que se lhe imponha a prevalência da paternidade socioafetiva, a fim de impedir sua pretensão.

6. O reconhecimento do estado de filiação constitui direito personalíssimo, indisponível e imprescritível, que pode ser exercitado, portanto, sem qualquer restrição, em face dos pais ou seus herdeiros.

7. A paternidade traz em seu bojo diversas responsabilidades, sejam de ordem moral ou patrimonial, devendo ser assegurados os direitos sucessórios decorrentes da comprovação do estado de filiação.

8. Todos os filhos são iguais, não sendo admitida qualquer distinção entre eles, sendo desinfluente a existência, ou não, de qualquer contribuição para a formação do patrimônio familiar.

9. Recurso especial desprovido. (REsp 1274240/SC, STJ, $3^{\text {a }}$ Turma, Rel. Min. Nancy Andrighi, julgado em: 08/10/2013)". Disponível em: <https://ww2.stj.jus.br/revistaeletronica/Abre_Documento.asp?sSeq $=1271958 \& \mathrm{sReg}=201102045237 \& \mathrm{sDa}-$ ta $=20131015 \&$ formato $=H T M L>$. Acesso em: 6 jul. 2014. 
cabimento pedido, por exemplo, seja pelos outros filhos seja pelo cônjuge, de declaração de falsa paternidade. ${ }^{28}$

Ainda há a peculiaridade da situação que, para aquele que consta como pai e toma o pleno conhecimento das consequências e circunstâncias que giram ao redor do seu gesto, e mesmo assim não providenciou a alteração do ato quando da ciência dessa situação, inexistir a possibilidade de arrependimento que venha a anular o registro. Arnaldo Rizzardo explica que se releva a consideração à pessoa humana quando a conduta do reconhecimento, com o passar do tempo, gera efeitos decisivos na vida da criança que foi, de fato, adotada. Dessa circunstância forma-se a paternidade socioafetiva. ${ }^{29}$

O Superior Tribunal de Justiça decide e define a questão. Mas faz consideração importante nos casos em que, mesmo quando ocorrida a adoção à brasileira, o filho postula, busca a paternidade biológica. Então, a paternidade socioafetiva não pode ser óbice a tal direito. ${ }^{30}$ Por outro lado, a Corte tem a posição de que a tese sobre o prevalecimento da paternidade socioafetiva sobre a paternidade biológica deve ser analisada com ponderação. A regra desta prevalência, assim, é no sentido de quando o pai registral, e, portanto verificada a paternidade so-

28 RIZZARDO, Arnaldo. Direito de familia. 8. ed. Rio de Janeiro: Forense, 2011, p. 531.

29 Idem.

30 DIREITO CIVIL. FAMÍLIA. RECURSO ESPECIAL. AÇÃO DE INVESTIGAÇÃO DE PATERNIDADE. VÍNCULO BIOLÓGICO COMPROVADO. "ADOÇÃO À BRASILEIRA”. PATERNIDADE SOCIOAFETIVA. INEXISTÊNCIA DE ÓBICE AO RECONHECIMENTO DA PATERNIDADE BIOLÓGICA BUSCADA PELA FILHA REGISTRAL.

1. Nas demandas sobre filiação, não se pode estabelecer regra absoluta que recomende, invariavelmente, a prevalência da paternidade socioafetiva sobre a biológica. É preciso levar em consideração quem postula o reconhecimento ou a negativa da paternidade, bem como as circunstâncias fáticas de cada caso.

2. No contexto da chamada "adoção à brasileira", quando é o filho quem busca a paternidade biológica, não se lhe pode negar esse direito com fundamento na filiação socioafetiva desenvolvida com o pai registral, sobretudo quando este não contesta o pedido.

3. Recurso especial conhecido e provido. (REsp 1256025/RS, STJ, $3^{\mathrm{a}}$ Turma, Rel. Min. João Otávio de Noronha, julgado em: 22/10/2013). Disponível em: < https://ww2.stj.jus. $\mathrm{br} /$ revistaeletronica/Abre_Documento.asp?sSeq=1276644\&sReg=201101188534\&sData=20140319\&formato=HTML $>$. Acesso em: 2 jun. 2014. 
cioafetiva, busca negar a paternidade. De tal sorte que a jurisprudência, neste contexto, é no sentido da improcedência, eis que já efetivada a relação entre pai e filho. ${ }^{31}$ Mas pode ocorrer situação fática que não demonstre a ocorrência da paternidade socioafetiva como nos moldes aqui trazidos. É que, segundo o que se registra, a prevalência da paternidade biológica foi comprovada ante a peculiaridade da ausência de demonstração de paternidade socioafetiva. ${ }^{32}$

\section{1 Adoção à brasileira e crime}

A adoção à brasileira, segundo o direito penal, mais especificamente o art. 242 do Código Penal, é conduta tipificada como crime $^{33}$. Ocorre quando alguém registra criança como filho, mas sem observar as determinações impostas pela legislação civil no tocante ao procedimento de adoção. Todavia, Arnaldo Rizzardo pondera que, na realidade, interessa ao direito a pessoa humana daquele que teve um

31 Como registrado anteriormente, na nota n. 24, constante nas páginas 206 e 207 desta revista, acerca do mesmo julgado do STJ.

32 Ementa: RECURSO DE APELAÇÃO. AÇÃO DE INVESTIGAÇÃO DE PATERNIDADE CUMULADA COM PETIÇÃO DE HERANÇA. ALEGAÇÃO DE PATERNIDADE SOCIOAFETIVA E CONLUIO COM INTUITO FINANCEIRO EM RELAÇÃO AO ELEVADO PATRIMÔNIO DO DE CUJUS. REGISTRO ESPONTÂNEO DE PATERNIDADE, POR TERCEIRO, ATRAVÉS DE INSTRUMENTO PARTICULAR. NECESSIDADE DE RELAÇÃO SOCIOAFETIVA QUE NÃO SE COMPROVA NOS AUTOS. ADOÇÃO À BRASILEIRA. PREVALÊNCIA DA PATERNIDADE BIOLÓGICA, COMPROVADA, ANTE A PECULIARIDADE DE AUSÊNCIA DE DEMONSTRAÇÃO DE PATERNIDADE SOCIOAFETIVA EM RELAÇÃO AO REGISTRO ANTERIOR. JUSTA POSTULAÇÃO DO DIREITO SUCESSÓRIO. SENTENÇA MANTIDA. APELAÇÃO DESPROVIDA. (Apelação Cível No 70043007749, Sétima Câmara Cível, Tribunal de Justiça do RS, Relator: Roberto Carvalho Fraga, Julgado em: 28/11/2012).

33 Art. 242. Dar parto alheio como próprio; registrar como seu o filho de outrem; ocultar recém-nascido ou substitui-lo, suprimindo ou alterando direito inerente ao estado civil: Pena - reclusão de dois a seis anos. Parágrafo único - Se o crime é praticado por motivo de reconhecida nobreza: Pena - detenção, de um a dois anos, podendo o juiz deixar de aplicar a pena. 
pai, considerada uma realidade que se perpetuou no tempo. ${ }^{34}$ Silvio Rodrigues, ao tratar da adoção, aduz que é negócio solene, eis que a legislação impõe determinada forma e, sem esta, o ato, além de não ter validade, não existe. $^{35}$

Fernando Capez e Stela Prado, ao comentarem a norma do art. 242 do Código Penal, referem que o objeto jurídico é a tutela do estado de filiação e a fé pública dos documentos inscritos no registro civil. Ainda, explicam que se trata de crime comum, ou seja, qualquer pessoa pode praticá-lo. Quanto ao sujeito passivo, inclui-se tanto o Estado como os lesados, pelo registro efetuado por aquele que não é o verdadeiro pai. Já o elemento subjetivo, alertam os autores, é o dolo, "consubstanciado na vontade livre e consciente de registrar como seu o filho de outrem". A tentativa de tal crime também é possível, consumando-se a conduta no instante da inscrição da criança alheia no registro civil. ${ }^{36}$
O entendimento em relação à adoção à brasileira é o de que não existe a possibilidade de desfazimento de um ato que foi levado a efeito, através da perfeita e inequívoca demonstração de vontade de quem, perante a sociedade, declara ser pai ou mãe de determinada criança, valendo-se da "verdade socialmente construída com base no afeto". De tal sorte que, através do tempo, mostra-se consumada relação de filiação, e que se criou e restou consolidada ${ }^{37}$.

Interessante a decisão ora trazida, cujo debate girou em torno do mencionado art. 242 do Código Penal. Nesta decisão, o Ministério Público (apelante) denunciou os recorridos em decorrência de registrarem filho de outra pessoa como sendo seus, conduta esta incursa nas sanções da norma mencionada. A sentença mantida em sede de recurso, concedeu o perdão judicial aos réus, reforçando o juiz que, quanto a este, trata-se de direito subjetivo das partes, e não uma facul-

34 RIZZARDO, Arnaldo. Direito de família. 8. ed. Rio de Janeiro: Forense, 2011, p. 532.

35 RODRIGUES, Silvio. Direito civil: direito de família, V. 6. 28. ed. São Paulo: Saraiva, 2008, p. 341.

36 CAPEZ, Fernando; PRADO, Stela. Código penal comentado. 3. ed. São Paulo: Saraiva, 2012, p. 510.

37 RIZZARDO, Arnaldo. Direito de família. 8. ed. Rio de Janeiro: Forense, 2011, p. 532. 
dade do julgador. E assim resumiu-se a sentença: "Fato relevante para o descobrimento da adoção à brasileira, que consta nos autos, foi a situação de: ' $O$ relativo sucesso dos acusados valeu-se da inexperiência dos funcionários do hospital e mesmo a ausência de maiores cuidados por conta do Registro Civil. Ao que tudo indica, a adoção à brasileira só foi descoberta quando o pequeno ERIK HENRIQUE foi levado ao posto de saúde, ocasião em que a funcionária GEANE DUTRA COELHO percebeu a irregularidade registral. Nesse passo, a conduta dos Denunciados amoldou-se perfeitamente à prevista no artigo 242 do estatuto repressivo. Não há hipótese de exclusão de antijuridicidade e também não pode ser considerada a exclusão da culpabilidade por conta do desconhecimento da lei. Embora sejam os Réus de cultura aparentemente baixa, é fato por demais sabido que as adoções são levadas a efeito pelo Poder Judiciário. Contudo, a cultura peculiar própria da quase bicentenária Comarca de Rio Pardo recomenda que haja detida apreciação acerca da hipótese de perdão judicial constante no parágra- fo único do dispositivo acima citado. Isso porque os elementos probatórios indicam que efetivamente o casal tinha objetivos nobres para a adoção de ERIK HENRIQUE. A mãe biológica é prostituta e buscava o apoio do casal para os cuidados do nenê. MÁRCIA ANDREA depôs no sentido de que tinha efetivamente o desejo de dar a criança por conta de não ter condições de dispensar seus cuidados. A amamentação do jovem ERIK HENRIQUE já foi feita pela mãe biológica na casa de SALETE. Havia um consenso entre todos de que o menino ficaria com o casal, o que certamente lhe proporcionaria uma vida com maiores cuidados, notadamente no âmbito afetivo. A nobreza do agir de CLEBER e SALETE deve ser reconhecida e o perdão judicial é um direito subjetivo do acusado e não de uma faculdade do julgador. Por fim, apenas registro que a Lei 3.719/2008 deixou por demais clara, ao dar nova redação aos artigos 386 e 397 do Código de Processo Penal que as hipóteses de extinção da punibilidade levam à absolvição e o perdão judicial é tal hipótese, a teor do artigo 107, IX, do diploma penal"”. ${ }^{38}$

38 Ementa: PARTO SUPOSTO. ARTIGO 242 DO CÓDIGO PENAL. ADOÇÃO À BRASILEIRA. PERDÃO JUDICIAL CONCEDIDO. SENTENÇA MANTIDA. Mãe do menor é prostituta e diante da impossibilidade de criar adequadamente o recém nascido o entregou aos réus. Para adequarem a realidade à certidão de nascimento, os réus se declararam pais do nascituro e lograram êxito em registrá-lo. Sentença concessiva de perdão judicial mantida. APELO NÃ̃O PROVIDO. (Apelação Crime No 70037954229 , Sexta Câmara Criminal, Tribunal de Justiça do RS, Relator: Cláudio Baldino Maciel, 


\section{CANCELAMENTO DO REGISTRO}

O Tribunal de Justiça do Estado de São Paulo, ao analisar arrependimento do pai que registrou o filho como se fosse seu, mesmo alegando coação (que, segundo a Corte, não restou comprovada), entendeu que o mencionado arrependimento não se presta para desconstituir a filiação ${ }^{39}$. Já neste outro caso julgado pelo Tribunal de Justiça do Distrito Federal, o entendimento foi o de que "caracteriza erro no registro civil de nascimento que autoriza a anulação do registro civil de nascimento, a declaração da filiação paterna que não condiz com a verdade real ${ }^{40}$ ".

O Tribunal de Justiça do Rio Grande do Sul, ao apreciar ação declaratória negativa de paternidade cumulada com pedido de cancelamento do registro civil, com base em indução em erro, determinou que, mesmo comprovada a existência da paternidade socioafetiva, esta não pode ser alicerçada em decorrência de situação de erro, se comprovado que uma

Julgado em: 23/09/2010). Disponível em: <http://migre-me/neNxE $>$. Acesso em: 2 jun. 2014.

39 Ementa: EMBARGOS INFRINGENTES - Negatória de paternidade - Acórdão embargado que reformou a sentença e julgou improcedente o pedido - Inconformismo - Desacolhimento - Autor que afirma na inicial que, mesmo havendo dúvidas acerca da paternidade, registrou o requerido em seu nome - Coação imputada à genitora do requerido não comprovada - Arrependimento que não é capaz de desconstituir a filiação - Inteligência dos arts. 1.609, caput, e 1.610 do Código Civil - Decisão mantida Embargos rejeitados. (Embargos Infringentes $n^{0}$. 0009350-19.2010.8.26.0533, TJSP, $5^{\text {a }}$ Câmara de Direito Privado, Rel. Des. J.L. Mônaco da Silva, julgado em: 15/01/2014.) Disponível em: $<$ http://esaj.tjsp.jus.br/cjsg/getArquivo.do?cdAcordao=7439823\&vlCa ptcha $=$ xssry $>$. Acesso em: 10 abr. 2014.

40 CIVIL. APELAÇÃO. AÇÃO NEGATÓRIA DE PATERNIDADE. ANULAÇÃO. REGISTRO CIVIL. DECORRÊNCIA. AÇÃO JUDICIAL. REALIZAÇÃO. EXAME DE DNA. CONCLUSÃO. INEXISTÊNCIA. PATERNIDADE. AUSÊNCIA. DEMONSTRAÇÃO. PATERNIDADE SÓCIOAFETIVA. REFORMA DA SENTENÇA. 1. Ainda que o reconhecimento da paternidade tenha ocorrido através de ação judicial com trânsito em julgado, o assento de nascimento é passível de anulação, por meio de provimento judicial, a requerimento do pai ou do filho, quando não espelhar a realidade biológica, uma vez que a paternidade é um direito natural e constitucional.

2. Caracteriza erro no registro civil de nascimento que autoriza a anulação do registro civil de nascimento, a declaração da filiação paterna que não condiz com a verdade real. 3. Embora se reconheça que a paternidade não deriva apenas do vínculo de consanguinidade, mas, sobretudo, em razão do laço de afetividade, é certo que se revela necessário o consenso das partes quanto à prevalência da paternidade socioafetiva sobre a 
das partes foi ludibriada na questão envolvendo a boa-fé. ${ }^{41}$ Já nesta outra decisão, a Corte gaúcha entendeu pelo cancelamento do registro, mesmo com a comprovação da existência da paternidade socioafetiva, que foi considerada como irrelevante. $\mathrm{O}$ caso tratou de pessoa que registrou filho como se fosse seu, embora a ciência, por aquele, de não ser o pai biológico da criança. $\mathrm{O}$ pedido de alimentos deu-se em face do pai biológico, havendo postulação, também, no sentido de anulação do registro efetuado pelo pai socioafetivo. E vejamos as lições do Relator, ao comparar pedidos de cancelamento de registros, quando feitos ora pelo perfilhado (discussão dos autos), e pelos ora perfilhantes:
"Se é o perfilhado quem busca a verdade biológica e, via de consequência, o afastamento da 'verdade jurídica', ou seja, a tão celebrada paternidade socioafetiva, que são incompatíveis entre si, não há como admitir que seja mantida a perfilhação. Ao contrário, se é o perfilhante quem busca a anulação do registro, se impõe, pois irrevogável o reconhecimento voluntário de filiação, que demonstre, de forma robusta, que a prática do seu ato se deveu à ocorrência de algum dos vícios de consentimento. Sendo assim, além de ser a busca da verdade biológica pelo filho perfilhado um 'direito personalíssimo, indisponível e imprescritível', nos termos do que dispõem os artigos 26 e 27 , da Lei ${ }^{\circ} 8.069 / 90$,

biológica, de forma a atender aos interesses de ambos, não podendo o Judiciário impor a paternidade sociofetiva, que, sobejamente, não condiz com a vontade de uma das partes.

4. Recurso conhecido e provido para, reconhecendo a nulidade no assentamento civil da Apelada, desconstituir a paternidade atribuída ao Apelante, com a exclusão de seu nome, e dos respectivos avós paternos, do seu registro civil.

(Apelação Cível no. 20100610138590, TJDFT, , Rel. Des. Getúlio De Moraes Oliveira, Rev. Des. Otávio Augusto, $3^{\text {a }}$ Turma Cível, julgado em: 03/07/2013)”. Disponível em: < http://juris.tjdft.jus.br/docjursisplsegjus/692693/692242.Pdf>. Acessom 10 abr. 2014.

41 Ementa: APELAÇÃO CÍVEL. DECLARATÓRIA NEGATIVA DE PATERNIDADE CUMULADA COM CANCELAMENTO DE REGISTRO CIVIL. ALEGAÇÃO DE INDUÇÃO EM ERRO. É a alegação de que foi induzido em erro pela afirmação da mãe das apeladas que dá amparo à pretensão recursal e impõe o provimento do recurso para possibilitar o prosseguimento do feito, com a produção das provas requeridas, pois a relação de paternidade socioafetiva aparentemente existente não pode se cristalizar sobre uma situação de erro, se efetivamente comprovado que o apelante foi ludibriado em sua boa-fé. DERAM PROVIMENTO. UNÂNIME. (Apelação Cível N ${ }^{\circ}$ 70050983907, Oitava Câmara Cível, Tribunal de Justiça do RS, Relator: Luiz Felipe Brasil Santos, Julgado em 13/12/2012). Disponível em: <http://migre-me/neNVp>. Acesso em: 7 jul. 2014. 
não tem o investigado, sequer, legitimidade para opor ao investigante a tese da paternidade socioafetiva, que constitui um direito de terceiro, o perfilhante - pai registral -, ou seja, não pode, em nome próprio, invocar contra o autor um direito de terceiro, com a agravante de não ser objeto do litígio. A sentença, portanto, merece reforma, pois, mesmo reconhecendo a existência da paternidade biológica, o que constitui o objeto da demanda, manteve a 'paternidade socioafetiva', negando ao autor o direito indisponível e imprescritível de ver declarada a verdade biológica, ou seja, negando vigência ao artigo 27 , da Lei $n^{\circ}$
8.069/90. Impositivo, pois, que seja declarada a paternidade biológica de A.O.V. em relação ao investigante B.S.G., em todos os seus efeitos, além de dever ser cancelado o registro de nascimento do autor levado a efeito por A.G., demandado no tocante à pretensão anulatória de registro civil deduzida na inicial". ${ }^{42}$

Para o êxito em relação à anulação de registro em discussão que envolva a adoção à brasileira, o Superior Tribunal de Justiça considerou que tal possibilidade é apenas viável "quando ainda não tiver sido constituído o vínculo de socioafetividade com o adotado". ${ }^{43}$ Podemos observar, ainda,

42 Ementa: APELAÇÃO CÍVEL. AÇÃO DE INVESTIGAÇÃO DE PATERNIDADE E ANULATÓRIA DE REGISTRO CIVIL E RETIFICAÇÕES DECORRENTES. BUSCA DA PATERNIDADE BIOLÓGICA PELO PERFILHADO QUE NÃO PARTICIPOU DO ATO REGISTRAL. PATERNIDADE BIOLÓGICA DEMONSTRADA ATRAVÉS DE EXAME DE DNA. ALIMENTOS. IRRELEVÂNCIA DA PATERNIDADE SOCIOAFETIVA. I - Aquele que perfilhou não pode revogar esse ato praticado de forma voluntária, a não ser que, de forma robusta e contundente, demonstre que a prática do ato foi decorrente de vício de consentimento. II - O reconhecido nessas circunstâncias pode, no entanto, investigar a sua paternidade biológica, direito personalíssimo, indisponível e imprescritível, expressamente previsto em lei. III - O investigado não pode invocar a manutenção da paternidade socioafetiva, o que constitui direito de terceiro, o perfilhante, para se opor à busca da paternidade biológica. IV - Diante disso, demonstrado, de forma inequívoca, através de exame de DNA, o vínculo genético entre investigado e investigante, não pode ser mantida a perfilhação sob o argumento de caracterização da paternidade socioafetiva, impondo-se que seja acolhida a pretensão investigatória da paternidade, em todos os seus efeitos, e determinado o cancelamento do registro levado a efeito pelo perfilhante. V- Reconhecida a paternidade biológica, se impõe sejam fixados alimentos devidos pelo investigado ao investigante. DERAM PROVIMENTO. (Apelação Cível N 70038071916, Oitava Câmara Cível, Tribunal de Justiça do RS, Relator: Alzir Felippe Schmitz, Julgado em 06/10/2011). Disponível em: $<$ http://migre-me/neO5b $>$. Acesso em: 7 jul. 2014.

43 RECURSO ESPECIAL - AÇÃO DECLARATÓRIA DE NULIDADE DE REGISTRO CIVIL - NEGATIVA DE PRESTAÇÃO JURISDICIONAL - ALEGAÇÃO DE 
julgamento proferido pelo Tribunal de Justiça do Rio Grande do Sul em idêntico sentido. ${ }^{44}$

Mas, o relevante, é o julgamento em questão, proferido pela Corte gaúcha. Neste caso restou decidido que não pode subsistir a adoção à brasileira. O fundamento, para tanto, foi o de que o registro deve refletir a realidade..$^{45}$ Já neste outro debate, a discussão girou em torno da adoção simulada, e impossibilidade de alte-

VIOLAÇÃO GENÉRICA - RECURSO ESPECIAL, NO PONTO, DEFICIENTEMENTE FUNDAMENTADO - APLICAÇÃO DA SÚMULA N. 284/STF - ADOÇÃO À BRASILEIRA - PATERNIDADE SOCIOAFETIVA - IMPOSSIBILIDADE, NA ESPÉCIE DE DESFAZIMENTO - RECURSO ESPECIAL IMPROVIDO.

1. O conhecimento do recurso especial exige a clara indicação do dispositivo, em tese, violado, bem assim em que medida o aresto a quo teria contrariado lei federal, o que in casu não ocorreu com relação à pretensa ofensa ao artigo 535 do Código de processo Civil (Súmula n. 284/STF).

2. Em se tratando de adoção à brasileira, a melhor solução consiste em só permitir que o pai-adotante busque a nulidade do registro de nascimento, quando ainda não tiver sido constituído o vínculo de socioafetividade com o adotado.

3. Recurso especial improvido. (REsp 1088157/PB, STJ, $3^{\text {a }}$ Turma, Rel. Min. MASSAMI UYEDA, julgado em 23/06/2009). Disponível em: $<$ https://ww2.stj.jus.br/revistaeletronica/Abre_Documento.asp?sSeq=896969\&sReg=200801995643\&sData=200908 04\&formato=HTML $>$. Acesso em: 6 jul. 2014.

44 Ementa: APELAÇÃO CÍVEL. AÇÃO NEGATÓRIA DE PATERNIDADE COM CANCELAMENTO DE REGISTRO E EXONERAÇÃO DE ALIMENTOS. INEXISTÊNCIA DE PATERNIDADE BIOLÓGICA. PAI REGISTRAL. VÍCIO DE VONTADE NÃO COMPROVADO. PATERNIDADE SOCIOAFETIVA. IRREVOGABILIDADE DO ATO REGISTRAL. À anulação do registro civil deve ser demonstrado um dos vícios do ato jurídico ou a ausência da relação de socioafetividade. No caso, embora comprovado que o autor não é o pai biológico do requerido, descabe a anulação do registro civil do menor pela não comprovação de qualquer dos vícios do ato jurídico e da existente relação socioafetiva existente entre eles. Recurso desprovido. (Apelação Cível No 70028072080, Sétima Câmara Cível, Tribunal de Justiça do RS, Relator: Ricardo Raupp Ruschel, Julgado em: 22/07/2009.)

45 Ementa: O REGISTRO DEVE SER O ESPELHO DA REALIDADE, NÃO PODENDO SEUS ASSENTAMENTOS ACOBERTAR UMA FALSIDADE IDEOLÓGICA. A ADOÇÃO À BRASILEIRA NAO PODE SUBSISTIR, POIS AFRONTA A VERDADE BIOLÓGICA E A LEI. 9 FLS. (Apelação Cível N 70003966272, Oitava Câmara Cível, Tribunal de Justiça do RS, Relator: José Ataídes Siqueira Trindade, Julgado em 04/04/2002.) 
ração do registro, com fundamento na não diferenciação entre os filhos. ${ }^{46}$ Em igual sentido a posição do Superior Tribunal de Justiça, que entendeu que, apesar da comprovação da adoção simulada, a situação consolidada, tanto na família como na sociedade, é base para a preservação da situação de fato. ${ }^{47}$

\section{REPERCUSSÃO GERAL}

Através da Emenda Constitucional n. 45/2004, houve importante inovação em relação aos pressupostos de admissibilidade para o recurso extraordinário, ou seja, deve ser levantada a repercussão geral da questão constitucional debatida no caso, e cuja

46 Ementa: REGISTRO DE NASCIMENTO. FALSIDADE. COMPORTAMENTO POSTERIOR DA MÃE REGISTRAL NO SENTIDO DE RATIFICAR O REGISTRO. PRINCÍPIOS ÉTICOS E CONSTITUCIONAIS DE PROTEÇÃO AO MENOR QUE LEVAM A CONCLUIR PELA CONFIGURAÇÃO DE ADOÇÃO SIMULADA. DESNECESSIDADE DE MODIFICAR O REGISTRO ANTE A INEXISTÊNCIA DE DIFERENCIAÇÃO ENTRE OS FILHOS. VOTO VENCIDO. DERAM PROVIMENTO, POR MAIORIA. (Apelação Cível No 598573681, Sétima Câmara Cível, Tribunal de Justiça do RS, Relator: Maria Berenice Dias, Julgado em 19/05/1999.) Disponível em: http://www1.tjrs.jus.br/site_php/consulta/consulta_processo.php?nome_comarca=Trib unal + de + Justi $\% E 7 a \& v e r s a o=\& v e r s a o \_f o n e t i c a=1 \&$ tipo $=1 \&$ id_comarca $=700 \&$ num processo_mask $=598573681 \&$ num $\_$processo $=598573681 \&$ codEmenta $=161569 \&$ temI ntTeor=false $>$. Acesso em: 3 jul. 2014.

47 FILIAÇÃO. ANULAÇÃO OU REFORMA DE REGISTRO. FILHOS HAVIDOS ANTES DO CASAMENTO, REGISTRADOS PELO PAI COMO SE FOSSE DE SUA MULHER. SITUAÇÃO DE FATO CONSOLIDADA HÁ MAIS DE QUARENTA ANOS, COM O ASSENTIMENTO TÁCITO DO CÔNJUGE FALECIDO, QUE SEMPRE OS TRATOU COMO FILHOS, E DOS IRMÃOS. FUNDAMENTO DE FATO CONSTANTE DO ACÓRDÃO, SUFICIENTE, POR SI SÓ, A JUSTIFICAR A MANUTENÇÃO DO JULGADO.

Acórdão que, a par de reputar existente no caso uma "adoção simulada", reporta-se à situação de fato ocorrente na família e na sociedade, consolidada há mais de quarenta anos. Status de filhos. Fundamento de fato, por si só suficiente, a justificar a manutenção do julgado.

Recurso especial não conhecido. (REsp 119346/GO, STJ, 4a Turma, Rel. Min. Barros Monteiro, julgado em 01/04/2003)". Disponível em: $<$ https://ww2.stj.jus.br/revistaeletronica/Abre_Documento.asp?sSeq=400765\&sReg=199700101819\&sData=200306 23\&formato=HTML $>$. Acesso em: 3 jul. 2014. 
comprovação deve ser feita pelo recorrente ${ }^{48}$, de acordo com os ditames da Constituição Federal. ${ }^{49}$

Devido à relevância que a discussão envolvendo a paternidade socioafetiva alcança, o tema chegou ao Supremo Tribunal Federal, e que discute se aquela tem ou não prevalência em relação à paternidade biológica. De tal modo que existência da repercussão geral à matéria foi reconhecida: ${ }^{50}$

Decisão: O Tribunal, por maioria, reputou constitucional a questão, vencido o Ministro Marco Aurélio. Não se manifestaram os Ministros Gilmar Mendes, Joaquim Barbosa, Ricardo Lewandowski e Cármen Lúcia. O Tribunal, por maioria, reconheceu aexistência de repercussão geral da questão constitucional suscitada, vencido o Ministro Marco Aurélio. Não se manifestaram os Ministros Gilmar Mendes, Joaquim Barbosa, Ricardo Lewandowski e Cármen Lúcia. Ministro LUIZ FUX Relator.

\section{HIPÓTESE DE DANOS EXTRAPATRIMONIAIS EM RAZÃO DA OMISSÃO, PELA MÃE, QUANTO À VERDADEIRA PATERNIDADE}

É certo que a paternidade socioafetiva, quando comprovada, e em razão da afetividade, vincula pai e mãe à criança. Todavia, indagamos o seguinte: nos casos de omitida a real paternidade, pela mãe, existe a pos-

48 PORTO, Sérgio Gilberto; USTÁRROZ, Daniel. Manual dos recursos cíveis. 4. ed. Porto Alegre: Livraria do Advogado, 2013, p. 254.

49 Art. 102. Compete ao Supremo Tribunal Federal, precipuamente, a guarda da Constituição, cabendo-lhe: [...] § $3^{\circ}$ No recurso extraordinário o recorrente deverá demonstrar a repercussão geral das questões constitucionais discutidas no caso, nos termos da lei, a fim de que o Tribunal examine a admissão do recurso, somente podendo recusá-lo pela manifestação de dois terços de seus membros. [...].

50 Ementa: RECURSO EXTRAORDINÁRIO COM AGRAVO. DIREITO CIVIL. AÇÃO DE ANULAÇÃO DE ASSENTO DE NASCIMENTO. INVESTIGAÇÃO DE PATERNIDADE. IMPRESCRITIBILIDADE. RETIFICAÇÃO DE REGISTRO. PATERNIDADE BIOLÓGICA. PATERNIDADE SOCIOAFETIVA. CONTROVÉRSIA GRAVITANTE EM TORNO DA PREVALÊNCIA DA PATERNIDADE SOCIOAFETIVA EM DETRIMENTO DA PATERNIDADE BIOLÓGICA. ART. 226, CAPUT, DA CONSTITUIÇÃO FEDERAL. PLENÁRIO VIRTUAL. REPERCUSSÃO GERAL RECONHECIDA. (ARE 692186 RG/DF, STF, REL. Min. Luiz Fux, julgado em 29/11/2012). Disponível em: < http://redir.stf.jus.br/paginadorpub/paginador. jsp?docTP=TP\&docID=3419008>. Acesso em: 2 jun. 2014. 
sibilidade de condenação, por danos imateriais, em razão de tal conduta? A jurisprudência do Superior Tribunal de Justiça responde tal questão.

A Corte, ao analisar a omissão da paternidade, considerou que o desco- nhecimento do fato de não ser o pai biológico dos filhos gerados durante $o$ casamento atinge a dignidade e a honra subjetiva do marido, justificando a reparação pelos danos morais. ${ }^{51}$ Neste outro debate, a indenização por danos

51 Marido que é enganado sobre quem é o verdadeiro pai das crianças criadas por ele tem direito de receber indenização da mulher. O entendimento é da $3^{a}$ Turma do Superior Tribunal de Justiça. A Turma garantiu a um pai indenização de R \$ 200 mil. Motivo: ele foi enganado pela ex-mulher, durante 20 anos, sobre a verdadeira paternidade biológica dos dois filhos nascidos em seu casamento.

O caso de omissão de paternidade chegou ao Superior Tribunal de Justiça em recursos especiais ajuizados pelas duas partes. $\mathrm{O}$ ex-marido pediu, em síntese, aumento do valor da indenização com a inclusão da prática do adultério, indenização por dano material pelos prejuízos patrimoniais sofridos e ainda que o ex-amante e atual marido da sua ex-mulher respondesse, solidariamente, pelos danos morais. A ex-mulher queria reduzir o valor da indenização arbitrado em primeira instância e mantido pelo Tribunal de Justiça do Rio de Janeiro.

Por 3 a 2, a $3^{\text {a }}$ Turma do STJ, acompanhando o voto da relatora, ministra Nancy Andrighi, rejeitou todos os pedidos formulados pelas partes e manteve o valor da indenização fixado pela Justiça fluminense. Segundo a relatora, o desconhecimento do fato de não ser o pai biológico dos filhos gerados durante o casamento atinge a dignidade e a honra subjetiva do marido e justifica a reparação pelos danos morais.

Para a ministra, a ex-mulher transgrediu o dever da lealdade e da sinceridade ao omitir do marido, deliberadamente, a verdadeira paternidade biológica dos filhos gerados no casamento.

Sobre o pedido de indenização ao amante, a ministra sustentou que não há como atribuir responsabilidade solidária, pois não existem nos autos elementos que demonstrem colaboração culposa ou conduta ilícita que a justifique. Para Nancy Andrighi, até seria possível vislumbrar descumprimento de um dever moral de sinceridade e honestidade, considerando que o ex-marido e o então amante eram amigos. "Entretanto, a violação de um dever moral não justificaria o reconhecimento da solidariedade prevista no artigo 1.518 do CC/16", concluiu a ministra.

Laços rompidos

Para a advogada especialista em Direito de Família, Ellen Cristina Gonçalves, sócia do escritório Pires \& Gonçalves Advogados, marido ou mulher enganados têm direito a indenização. "Existe dano moral quando alguém é privado da verdade. Há de se ressaltar que o valor da indenização serve, principalmente, para inibir condutas como essas", afirma a advogada.

O advogado Roberto Godoy Jr., especialista em Direito Civil do escritório Maluly Jr. Advogados, lembra que costuma ocorrer o inverso. É a mulher traída que pede 
extrapatrimoniais também se deu em decorrência da omissão da condição de pai. Ficou registrado no julgamento que existe transgressão do dever de sinceridade quando o cônjuge, deliberadamente, omite a verdadeira paternidade biológica dos filhos gerados na constância do casamento, mantendo o consorte na ignorância. De tal sorte que o desconhecimento do fato de não ser o pai biológico dos filhos gerados durante o casamento atinge a honra subjetiva do cônjuge, justificando a reparação pelos danos morais suportados. ${ }^{52}$

indenização do ex-marido. Também chama a atenção o valor da indenização. "Duzentos mil reais é uma quantia elevada se compararmos ao que é estipulado normalmente pelo Poder Judiciário", observa. De qualquer forma, considera que "o dano moral se configura quando há agressão a liberdade, honra e a pessoa da família, como ocorreu neste caso".

Último a saber

O ex-marido alegou que, depois de homologada a separação judicial, foi alertado por vizinhos e pessoas de seu convívio social, inclusive colegas de trabalho, de que havia dúvidas quanto à paternidade de sua filha caçula, nascida durante seu casamento com a mulher. O homem pediu exame de DNA e a dúvida foi desfeita: ele não era o pai da criança.

O ex-pai, um comerciante de Belo Horizonte entrou, então, com ação de indenização contra a ex-mulher para reparar os danos psíquicos que alega ter sofrido. Ele sustentou que ela omitiu deliberadamente quem era o verdadeiro pai da criança, o que abalou sua honra e dignidade.

Em sua defesa, a mulher alegou que só soube que seu marido não era o pai da criança quando tomou conhecimento do resultado do exame de DNA. Acusou também o exmarido de ter um comportamento agressivo e libertino, e da prática de atos sexuais excêntricos e relacionamentos homossexuais.

A primeira instância acatou o pedido do homem e fixou a indenização por danos morais em R\$ 15 mil, considerando a frustração e melancolia que o ex-marido passou ao ser subtraído, repentinamente, de sua condição de pai. O Tribunal de Justiça mineiro manteve a sentença. Ressaltou que "o casamento faz nascer entre os cônjuges direitos e deveres recíprocos, destacando-se entre eles os deveres de lealdade, respeito e fidelidade". Disponível em: $<$ http://www.conjur.com.br/2007-set-17/marido enganado_paternidade_ganha_indenizacao>. Acesso em: 13 abr. 2013.

52 Direito civil e processual civil. Recursos especiais interpostos por ambas as partes. Reparação por danos materiais e morais. Descumprimento dos deveres conjugais de lealdade e sinceridade recíprocos. Omissão sobre a verdadeira paternidade biológica. Solidariedade. Valor indenizatório.

- Exige-se, para a configuração da responsabilidade civil extracontratual, a inobservância de um dever jurídico que, na hipótese, consubstancia-se na violação dos deveres conjugais de lealdade e sinceridade recíprocos, implícitos no art. 231 do CC/16 (correspondência: art. 1.566 do $\mathrm{CC} / 02$ ). 
Em igual sentido foi o julgamento envolvendo a omissão sobre a verdadeira paternidade biológica de filho nascido na constância do casamento. O cônjuge que deliberadamente omite a verdadeira paternidade biológica do filho gerado na constância do casamento viola o dever de boa-fé, ferindo a dignidade do companheiro (honra subjetiva) induzido em erro acerca de relevantíssimo aspecto da vida que é o exercício da paternidade, verdadeiro projeto de vida. ${ }^{53}$

Pelos julgamentos trazidos que tratam de casos envolvendo a omissão da paternidade, pela mãe, observamos

- Transgride o dever de sinceridade o cônjuge que, deliberadamente, omite a verdadeira paternidade biológica dos filhos gerados na constância do casamento, mantendo o consorte na ignorância.

- O desconhecimento do fato de não ser o pai biológico dos filhos gerados durante o casamento atinge a honra subjetiva do cônjuge, justificando a reparação pelos danos morais suportados.

- A procedência do pedido de indenização por danos materiais exige a demonstração efetiva de prejuízos suportados, o que não ficou evidenciado no acórdão recorrido, sendo certo que os fatos e provas apresentados no processo escapam da apreciação nesta via especial. Para a materialização da solidariedade prevista no art. 1.518 do CC/16 (correspondência: art. 942 do CC/02), exige-se que a conduta do "cúmplice" seja ilícita, o que não se caracteriza no processo examinado.

- A modificação do valor compulsório a título de danos morais mostra-se necessária tão-somente quando o valor revela-se irrisório ou exagerado, o que não ocorre na hipótese examinada.

Recursos especiais não conhecidos. (REsp 742137/RJ, Superior Tribunal de Justiça, $3^{\mathrm{a}}$ Turma, Rel. Min. Nancy Andrighi, julgado em 21/08/2007). Disponível em: $<$ https:// ww2.stj.jus.br/revistaeletronica/Abre_Documento.asp?sSeq=637864\&sReg=2005006 02952\&sData $=20071029 \&$ formato $=$ HTML $>$. Acesso em: 20 mar. 2014.

53 RECURSO ESPECIAL. DIREITO CIVIL E PROCESSUAL. DANOS MATERIAIS E MORAIS. ALIMENTOS. IRREPETIBILIDADE. DESCUMPRIMENTO DO DEVER DE FIDELIDADE. OMISSÃO SOBRE A VERDADEIRA PATERNIDADE BIOLÓGICA DE FILHO NASCIDO NA CONSTÂNCIA DO CASAMENTO. DOR MORAL CONFIGURADA. REDUÇÃO DO VALOR INDENIZATÓRIO.

1. Os alimentos pagos a menor para prover as condições de sua subsistência são irrepetíveis.

2. O elo de afetividade determinante para a assunção voluntária da paternidade presumidamente legítima pelo nascimento de criança na constância do casamento não invalida a relação construída com o pai socioafetivo ao longo do período de convivência. 3. O dever de fidelidade recíproca dos cônjuges é atributo básico do casamento e não se estende ao cúmplice de traição a quem não pode ser imputado o fracasso da sociedade conjugal por falta de previsão legal. 
que as indenizações são concedidas para tais casos. A boa-fé tenta ser preservada, quando atingida, assim como relevada a honra ferida da vítima da omissão, além de ressaltado o princípio da dignidade da pessoa humana.

\subsection{Hipótese de danos extrapatrimoniais pela desconstituição da paternidade}

Rolf Madaleno diz que, quando rompido o relacionamento, seja a título de casamento, seja a título de união estável, situação muito comum ocorre no sentido de o pai registral buscar a falsidade ideológica promovendo a ação de desconstituição do registro, eis que não há correspondência para com a verdade biológica. Todavia, alerta o autor mencionado que tais ações que, nos casos de paternidade socioafetiva e a sua desconstituição, não têm sido alvo de tutela jurisdicional. Como consequência, o vínculo do registro, mesmo contrariando o liame biológico, tem sido mantido, eis que passa a produzir efeitos jurídicos que transcendem a origem genética da filiação, "até porque a relação de filiação é muito mais uma conquista de coração do que da biologia". ${ }^{54}$

Adquire importância jurídica o agravo moral em face do filho que é chamado para responder a uma ação negatória de paternidade pelo pai socioafetivo, com o objetivo de desconstituição do registro de filiação.

4. O cônjuge que deliberadamente omite a verdadeira paternidade biológica do filho gerado na constância do casamento viola o dever de boa-fé, ferindo a dignidade do companheiro (honra subjetiva) induzido a erro acerca de relevantíssimo aspecto da vida que é o exercício da paternidade, verdadeiro projeto de vida.

5. A família é o centro de preservação da pessoa e base mestra da sociedade (art. 226 $\mathrm{CF} / 88$ ) devendo-se preservar no seu âmago a intimidade, a reputação e a autoestima dos seus membros.

6. Impõe-se a redução do valor fixado a título de danos morais por representar solução coerente com o sistema.

7. Recurso especial do autor desprovido; recurso especial da primeira corré parcialmente provido e do segundo corréu provido para julgar improcedente o pedido de sua condenação, arcando o autor, neste caso, com as despesas processuais e com os honorários advocatícios.

(REsp 922462 / SP, STJ, $3^{\text {a }}$ Turma, Rel. Min. Ricardo Villas Bôas Cueva, julgado em 04/04/2013). Disponível em: < https://ww2.stj.jus.br/revistaeletronica/Abre_Documento.asp?sSeq $=1221381 \&$ sReg $=200700301624 \&$ sData $=20130513 \&$ formato $=$ HT ML>. Acesso em: 28 mar. 2014.

54 MADALENO, Rolf. Curso de direito de família. 5. ed. Rio de Janeiro: Forense, 2013, p. 378. 
Muitas vezes a motivação dá-se por motivo desprezível daquele que foi abandonado em uma relação, em que pese ponderar Rolf Madaleno que, ainda assim, a criança não deixou de ser amada pelo pai socioafetivo. De tal sorte que submeter um filho socioafetivo a demandas negatórias, e que não pediu para ser registrado e também não pediu para ser tratado como filho natural, tal circunstância irá gerar um sofrimento muito grande, eis que tem de enfrentar ação de repúdio do pai, haja vista a intenção deste ao postular a revogação do registro, promovido de forma consciente. Inclusive, esta circunstância corre em sentido contrário ao da história pessoal da criança. Portanto, a conclusão é a de que a improcedência desses tipos de ação mostra-se correta. Ainda, o arrependimento do pai acarreta em verdadeira tortura psicológica para o filho, ocasionando, desta maneira, a devida reparação por danos imateriais ao filho, em virtude do abuso de direito pelo pai. Todavia, tal hipótese não pode fundamentar pretensões para os casos de registros inconscientes, cujo pai foi levado a imaginar que registrou o seu filho biológico, e com que jamais teve efetiva, consciente e consistente convivência. ${ }^{55}$

\section{CONCLUSÃO}

Entendemos que o tema, realmente, além de instigante, é extremamente relevante, pois incide diretamente nas relações familiares e, especialmente, nas crianças. Inclusive, como já referimos e demonstramos, é objeto de repercussão geral.

O predomínio da situação de fato até sobre o registro, como visto, ante a comprovação da afetividade, e de como a criança é apresentada pelos pais e vista na sociedade, pode levar à situação da paternidade socioafetiva. Além do que pode, também, ter predomínio em relação ao próprio processo de adoção, a adoção à brasileira, desde que comprovada a boa-fé dos envolvidos, a estabilidade da família, a ausência de vício de consentimento e até a nobreza do ato.

Mas é importante frisar o que foi tratado aqui no tocante da imprescritibilidade do reconhecimento biológico e, quanto à anulação do registro, esta depende de quem a busca, ou seja, se pelo filho objeto da paternidade socioafetiva, ou se por quem o registrou, mesmo sabendo que não é seu. Ainda, ensina José Afonso da Silva, que os filhos, havidos ou não da relação do casamento bem como a fa- 
mília, são objeto de proteção a nível constitucional..$^{56}$

Outro aspecto importante em relação à paternidade socioafetiva é a de que esta não se origina de modo automático e instantâneo. Os vínculos vão, com o passar do tempo, fortalecendo-se. Rolf Madaleno, inclusive, indica a expressão "filho do coração". Trata-se, portanto, de uma família desenvolvida através do tempo, e que vai encontrando sua própria identidade e estabilidade acerca de suas relações. ${ }^{57}$

Como vimos, a preocupação e tutela da família tem relação ímpar pelo legislador. A própria questão da adoção à brasileira, quando comprovada a paternidade socioafetiva, pode subsistir, mesmo sem o devido processo legal da adoção, que culmina em uma sentença e, também, pode ser relevada a conduta criminal tipificada pelo art. 242 do Código Penal, como anteriormente estudado. Claro que o caso concreto deve ser relevado. Todavia, tanto a doutrina quanto a jurisprudência selecionadas e analisadas no presente trabalho abrem os olhos da sociedade, no sentido da importância que se deve dar à família, aos filhos, ao registro de nascimento, a não omitir a paternidade. Inclusive, a improcedência de ações negatórias de paternidade em razão do arrependimento, pelo pai, quanto ao registro de nascimento, pode possibilitar condenações por danos imateriais em face do pai ao filho, como também observado.

O nosso objetivo jamais é o de esgotar a temática que, como pudemos perceber, é polêmica e também problemática. A nossa intenção é a de trazer para os leitores os conceitos que envolvem a filiação nos moldes aqui trabalhados, bem como as consequências que as atitudes dos pais (biológicos e/ ou socioafetivos), podem ocasionar aos filhos, às crianças. De modo que o presente artigo busca contribuir para aqueles que estudam o direito de família.

\section{REFERÊNCIAS}

BRASIL. Constituição da República Federativa do Brasil de 1988. DF, 5 out. 1988. Disponível em:
$<$ http://www.planalto.gov.br/ccivil_03/Constituicao/Constituicao. htm>. Acesso em: 25 mai. 2014.

56 SILVA, José Afonso da. Curso de direito constitucional positivo. 29. ed. São Paulo: Malheiros Editores, 2007, p. 851.

57 MADALENO, Rolf. Curso de direito de família. 5. ed. Rio de Janeiro: Forense, 2013, p. 378. 
BRASIL. Código Civil. DF, 10 jan. 2002. Disponível em: <http:// www.planalto.gov.br/ccivil_03/ LEIS/2002/L10406.htm>. Acesso em: 2 jun. 2014.

BRASIL. Código Penal. DF, 7 dez. 1940. Disponível em: <http:// www.planalto.gov.br/ccivil_03/ Decreto-Lei/Del2848.htm>. Acesso em: 7 jul. 2014.

CAPEZ, Fernando; PRADO, Stela. Código penal comentado. 3. ed. São Paulo: Saraiva, 2012.

DIAS, Maria Berenice. Manual de direito das famílias. 6. ed. São Paulo: Revista dos Tribunais, 2010.

DINIZ, Maria Helena. Curso de direito civil brasileiro. V. 5: Direito de família. 27. ed. São Paulo: Saraiva, 2012.

JUNIOR, Nelson Nery; NERY, Rosa Maria de Andrade. Código Civil comentado. 10. ed. São Paulo, Revista dos Tribunais, 2013.

MADALENO, Rolf. Curso de direito de família. 5. ed. Rio de Janeiro: Forense, 2013.
NORONHA, Carlos Silveira. Fundamentos e evolução histórica da família na ordem jurídica. Direito \& Justiça, V. 20, ano XXI, 1999.

PONTES DE MIRANDA; Francisco Cavalcanti. Tratado de direito de familia. V. 1, Direito matrimonial. ALVES, Vilson Rodrigues (Atual.). 1. ed. Campinas: Bookseller, 2001.

PORTO, Sérgio Gilberto; USTÁRROZ, Daniel. Manual dos recursos civeis. 4. ed. Porto Alegre: Livraria do Advogado, 2013.

RIZZARDO, Arnaldo. Direito de família. 8. ed. Rio de Janeiro: Forense, 2011.

RODRIGUES, Silvio. Direito civil: direito de família. V. 6. 28. ed. São Paulo: Saraiva, 2008.

SILVA, José Afonso da. Curso de direito constitucional positivo. 29. ed. São Paulo: Malheiros Editores, 2007.

VENOSA, Silvio de Salvo. Código Civil interpretado. São Paulo: Atlas, 2010. 